\title{
Shredding - A Novel Technology for the Processing of Tobacco Stems which Alters Cigarette Properties*
}

\author{
by George Fazekas \\ Rothmans of Pall Mall Limited, Toronto, Ontario, Canada
}

\section{SUMMARY}

Shredding is a novel process for the utilization of tobacco stems. Stem pieces are forced between large, counter-rotating toothed blades where they are stripped lengthwise into thin, fibrous particles. When compared to the process of rolling and cutting, shredding produces particles having superior bulk filling capacity, cigarette filling index and end stability.

The thin, fibrous structure of shredded stem modifies the burn characteristics of the cigarette. Pressure drop and burn rate are reduced, nicotine delivery is enhanced, and, most importantly, carbon monoxide delivery is significantly reduced. These changes provide a significant potential for product improvement.

The use of shredded stem has no effect on "tar" delivery. Replacing cut rolled stem with shredded stem has no detectable effect on the chemical composition of the tobacco or on the flavour characteristics of the cigarettes.

\section{ZUSAMMENFASSUNG}

Zur Nutzung der Rippen des Tabakblattes wird neuerdings die Zerfaserungsmethode eingesetzt. Die Rippenstũcke werden zwischen große, gegenläufige, gezahnte Sägemesser gepreßt, die sie der Länge nach in dūnne, faserige Teilchen reißen. Im Vergleich zu der Verarbeitungstechnik des Walzens und Schneidens ent-

\footnotetext{
* Received: 17th May 1985 - accepted: 18th December 1985.

Presented at the 38th Tobacco Chemist's Research Conference, Adanta, Georgia, U.S.A., in 1984.
}

steht durch das Zerfasern Rippengut mit besserem Schũttgewicht, besserer Stopfdichte und geringerem Endenausfall.

Durch die dünne, faserige Struktur der Rippenteilchen verändern sich die Brenneigenschaften der Zigarette. Zugwiderstand und Abbrenngeschwindigkeit verringern sich, die Nikotinausbeute steigt an, und von großer Bedeutung ist, daß die Ausbeute an Kohlenmonoxid signifikant zurückgeht. Diese Veränderungen könnten für wichtige Produktverbesserungen genutzt werden.

Auf die Kondensatausbeute hat die Verwendung zerfaserter Rippen keinen EinfluB. Bei Zigaretten mit zerfaserten anstelle von gewalzten und geschnittenen Rippen ist eine Veränderung der chemischen Zusammensetzung des Tabaks und der Aromaeigenschaften der Zigarette nicht feststellbar.

\section{RESUME}

Depuis peu de temps, on a recours à la méthode de défibrage pour l'utilisation des côtes des feuilles de tabac. Les morceaux de côtes sont pressés entre de grandes lames à dents de scie tournant en sens contraire l'une de l'autre qui dilacèrent les côtes longitudinalement en particules minces et fibreuses. Comparativement aux techniques de laminage et de hachage, le défibrage permet d'améliorer la densité apparente et la compacité, ainsi que de réduire les pertes par les bouts.

La combustibilité des cigarettes se trouve modifiée du fait de la structure mince et fibreuse des particules de côtes. La résistance au tirage et la vitesse de combus- 
Figure 2.

Comparison of shredded stem (right) and cut rolled stem.

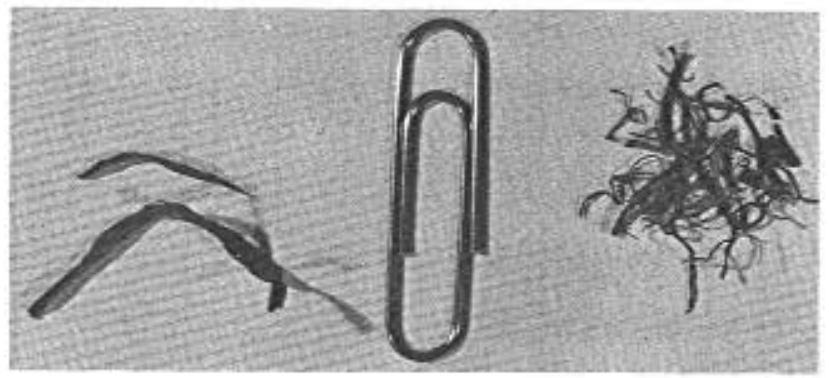

a: $1 \mathrm{mg}$ each

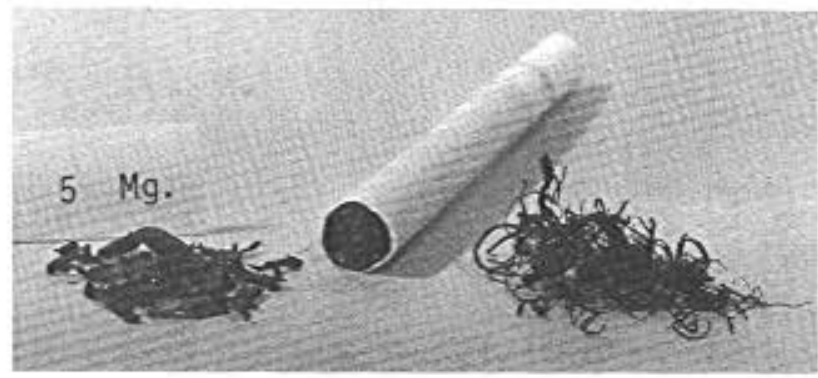

b: $5 \mathrm{mg}$ each

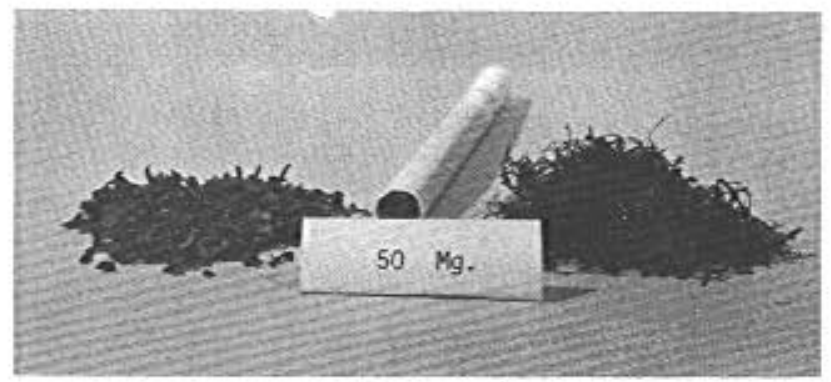

c: $50 \mathrm{mg}$ each 
tion diminuent tandis que le rendement en nicotine augmente et, ce qui revêt une grande importance, la production de monoxyde de carbone diminue de façon significative. Ces modifications pourraient être mises à profit pour d'importantes améliorations du produit.

L'utilisation de côtes défibrées n'a aucune influence sur le rendement en condensat. Si l'on prend des côtes défibrées au lieu de côtes laminées et hachées, on n'observe pas de modification de la composition chimique du tabac ni des caractéristiques organoleptiques de la cigarette.

\section{INTRODUCTION}

The purpose of this investigation was to compare the quality of the stem shredding process to that of the conventional process of rolling and cutting of stem.

Superior quality was measured in terms of improvement in filling capacity, increased product development potential, and improvements in other product characteristics.

\section{SHREDDING PROCESS}

The shredding process begins with threshed stem taken from storage (see Figure 1). The stem is conditioned to $50 \%-55 \%$ moisture content and this moisture is allowed to soak into the stem structure in a 90 -minute time delay silo. At the exit of the time delay silo, the wet stem passes through a steaming tube and into the shredder. Here, counter-rotating toothed blades strip the stem lengthwise into long, thin, fibrous particles. Exiting the shredder, the stem particles are conveyed through a hot air pneumatic tube predrier into a rotary drier. The dried stem at $19 \%-21 \%$ moisture content is carried over a vibrating screen conveyor to remove fine particles. The product of the shredding process is then packed for shipment to the manufacturing plant.

\section{EXPERIMENTAL METHOD}

The investigation into the characteristics of shredded stem was divided into four stages.

The first stage was the preparation of two identical lots of threshed stem. This was done by carefully blending the stem in a large blending silo and then discharging the silo into cases. Cases were assigned alternately to the shredded stem process and the cut rolled stem (CRS) process. Each of the lots was blended a second time to ensure homogeneity within the lots as well as between the lots.

The second stage consisted of the processing of the stems. Cut rolled stem (CRS) was produced in our production plant using a double wetting expansion process. Shredded stem was produced in our plant scale production line. (The shredded stem was not expanded.)
Figure 1.

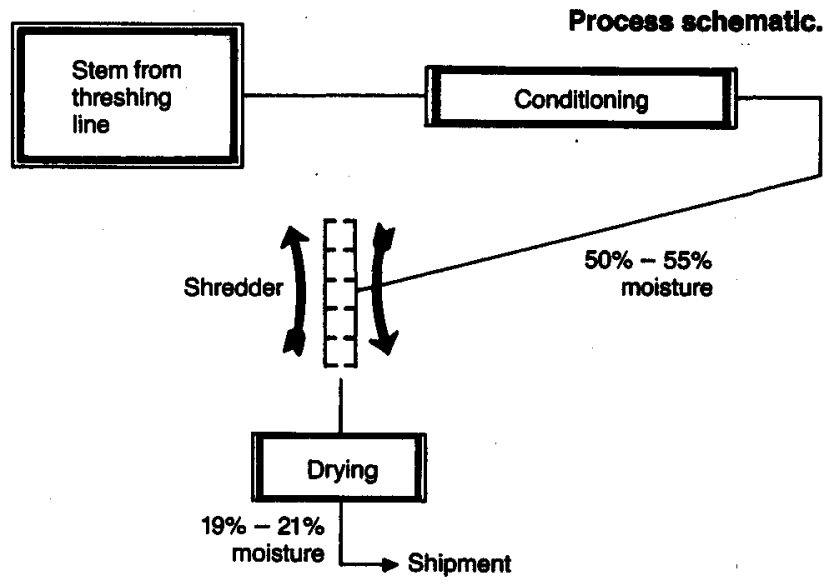

A detailed comparison of the shredding and cut rolled stem processes is given in Appendix 1.

The next stage was the blending of the two stem products with a single homogeneous lot of cut lamina and the subsequent use of these tobaccos to produce approximately 300,000 cigarettes containing shredded stem and another 300,000 cigarettes containing cut rolled stem.

The blends were produced to contain $26 \%$ stem and $74 \%$ lamina. Cigarettes were manufactured on Molins Mk 8 and Hauni PROTOS making machines.

The final stage consisted of collecting representative samples of the tobacco components from various processing locations and representative samples of the cigarettes from each of the makers and each of the stem processes.

These samples were then analyzed to determine their physical and chemical as well as smoking and flavour characteristics.

\section{FILLING CAPACITY IMPROVEMENTS}

Shredded stem was found to have a significantly greater bulk volume and hence a significantly greater filling capacity than cut rolled stem.

This is apparent on visual examination. The long, fibrous structure of shredded stem is unlike the more bulky structure of cut rolled stem. Figure 2 demonstrates the effect of this structural difference on the bulk volumes of the two products. Shredded stem is seen to have a greater bulk volume than an equal weight of cut rolled stem.

Objective tests were conducted to determine the extent of this improvement in bulk volume and to determine the degree of improvement in product resiliency.

The bulk filling capacity of the shredded stem and cut rolled stem were measured with a Borgwaldt digital densimeter. Results indicated an $18 \%$ improvement in the compressed bulk volume of the shredded stem compared to that of the cut rolled stem (Figure 3). 
Figure 3.

Bulk filling capacity of stem: $18 \%$ improvement.

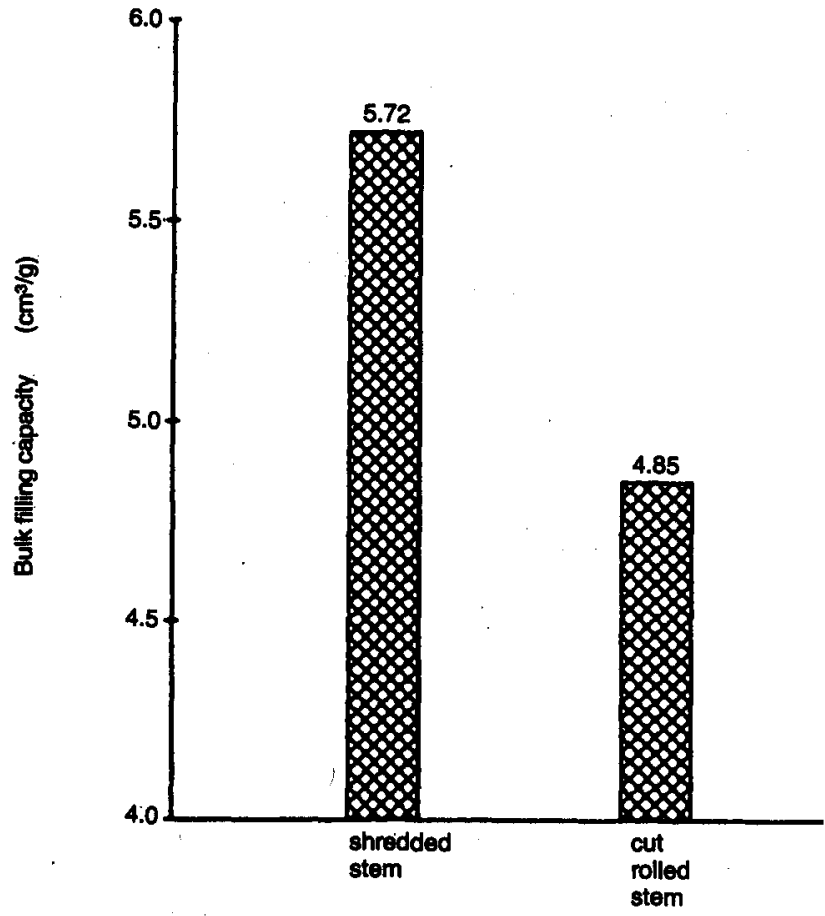

Figure 5.

Borgwaldt compression of clgarettes: $6.7 \%$ Improvement.

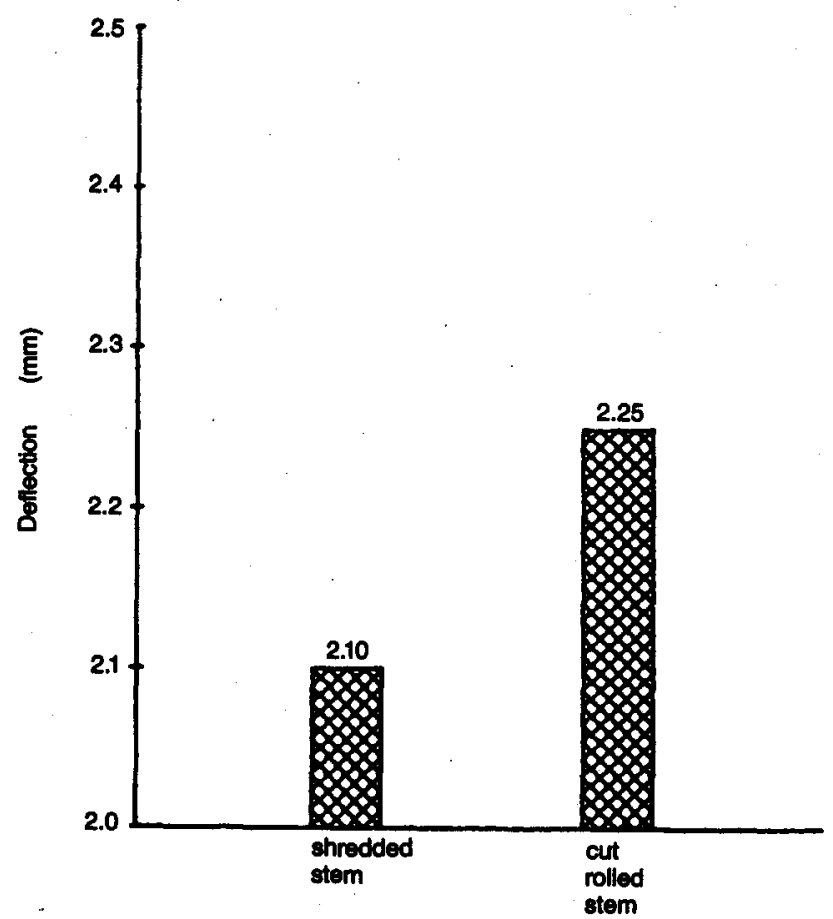

Figure 4.

Bulk filling capacity of blend: $3.6 \%$ improvement.

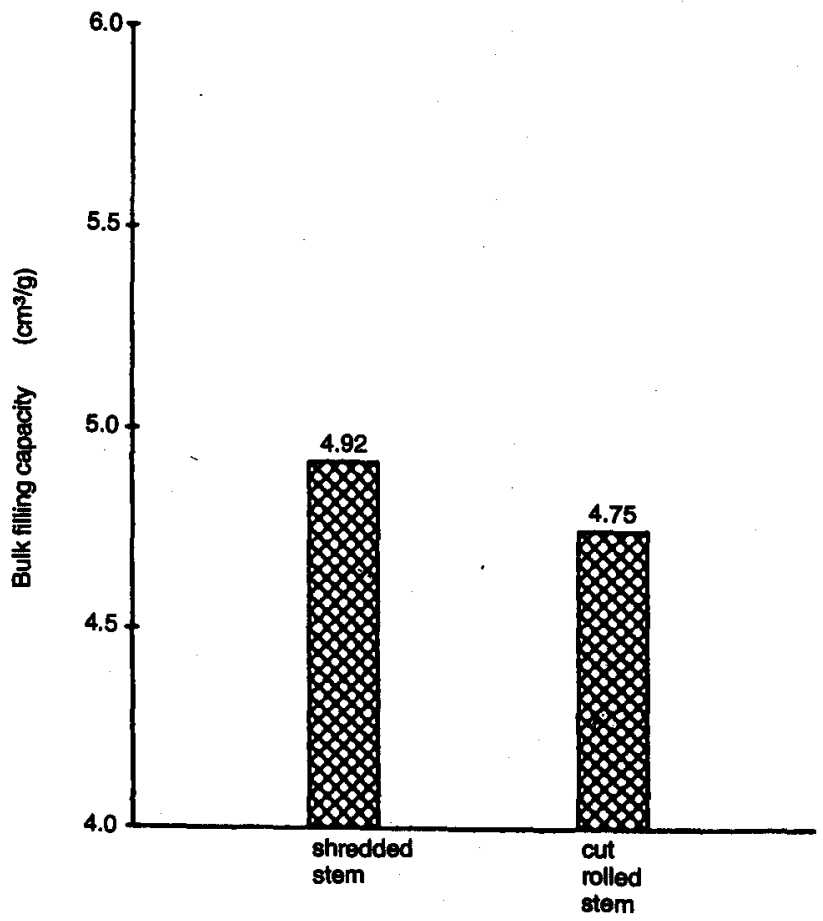

Flgure 6.

Brinkmann hardness of clgarettes: $8.3 \%$ Improvement.

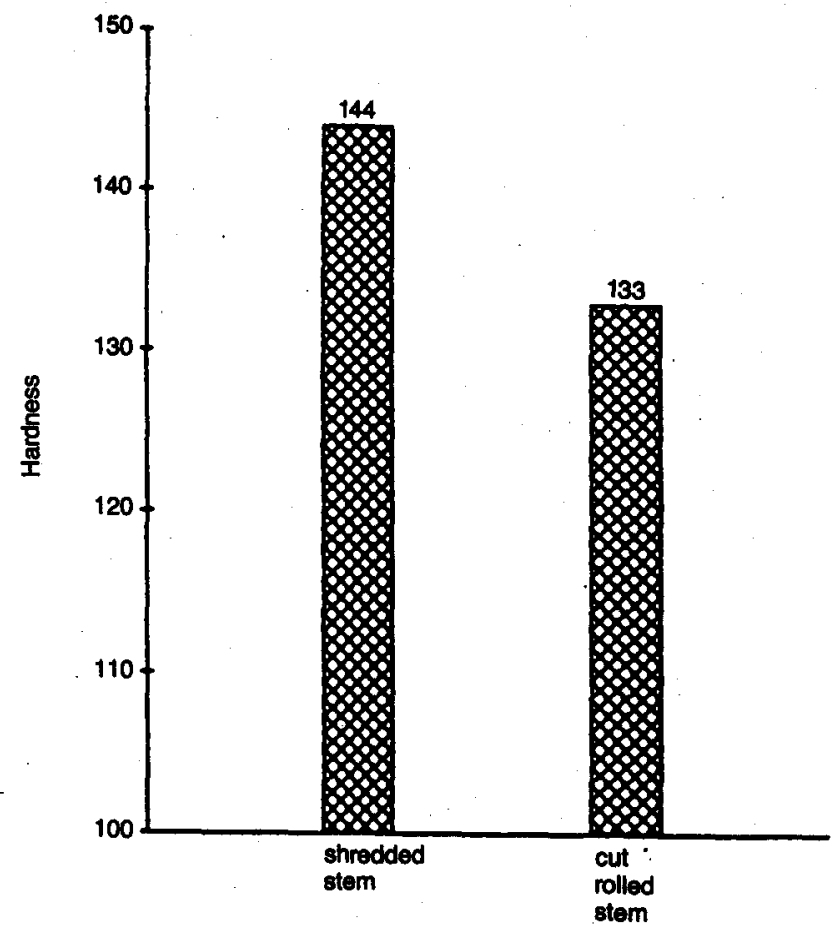




\section{Figure 7.}

Filling capaclty of clgarettes: $41 \mathrm{mg}$ tobacco saving per cigarette, 1.e. 4.5\% improvement.

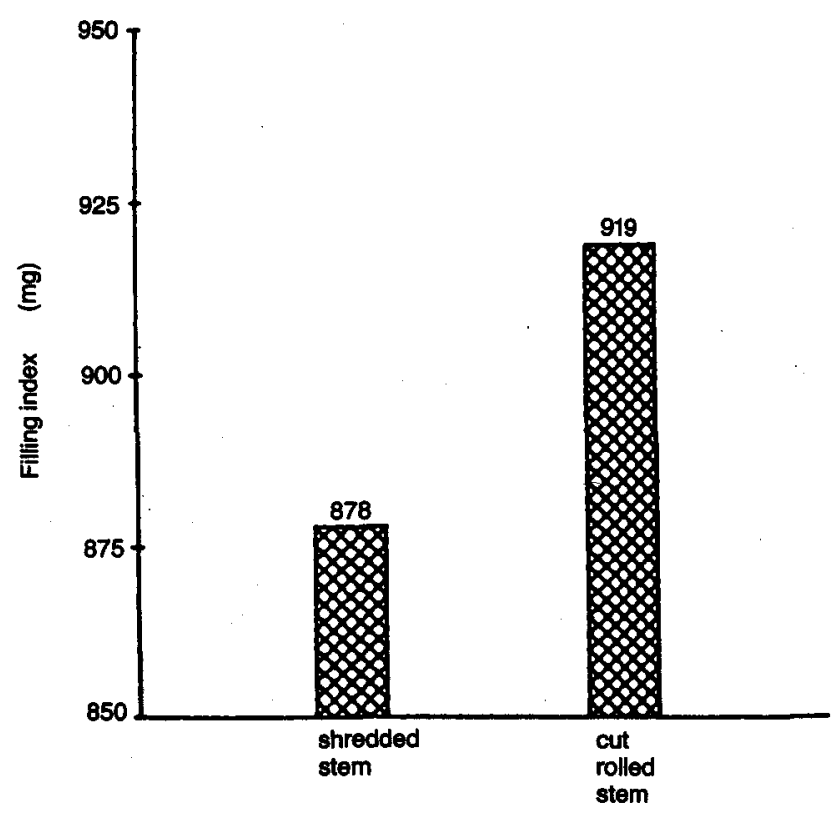

Figure 9.

Nicotine delivery: $13 \%$ improvement.

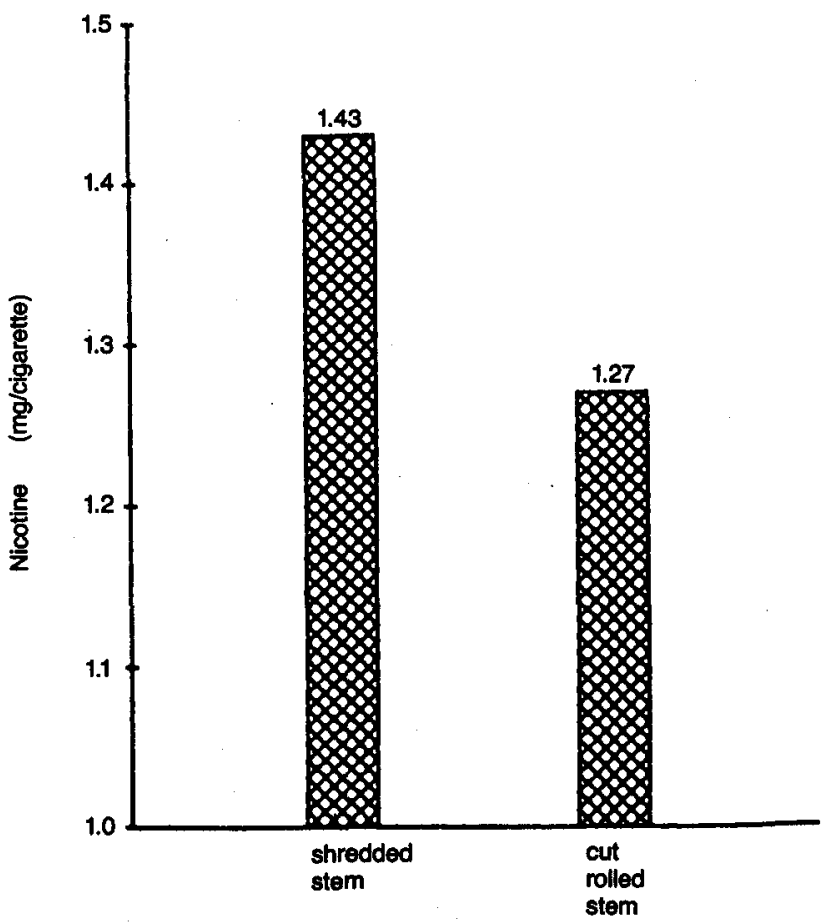

Flgure 8.

Cigarette pressure drop: 13\% Improvement.

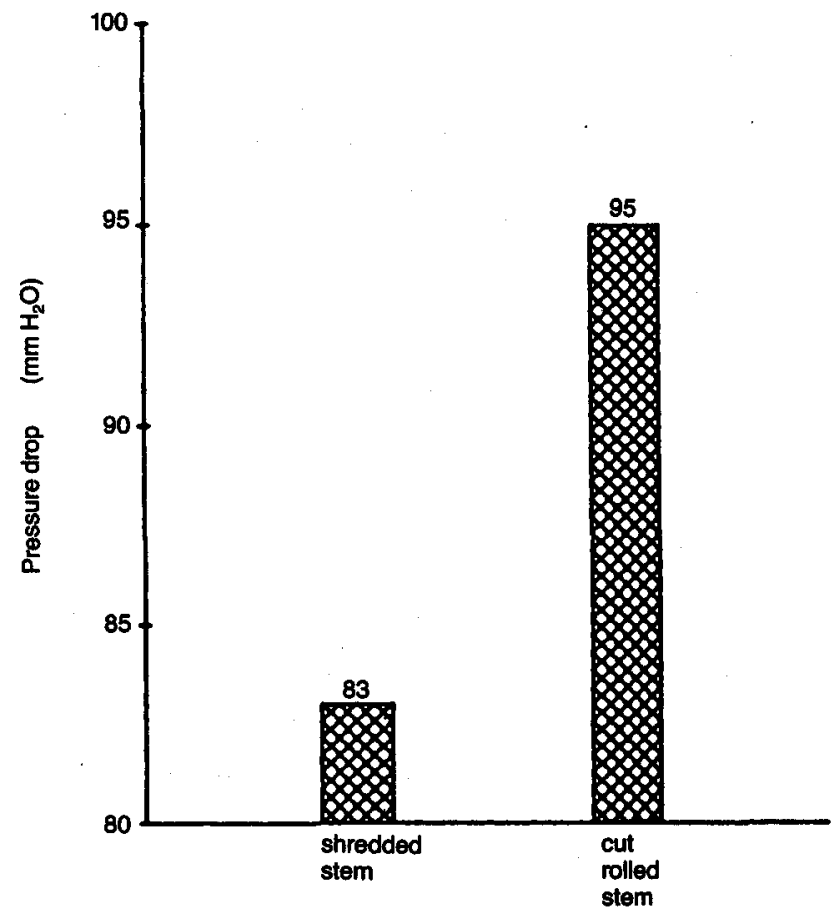

Flgure 10.

Carbon monoxide delivery: $22 \%$ Improvement.

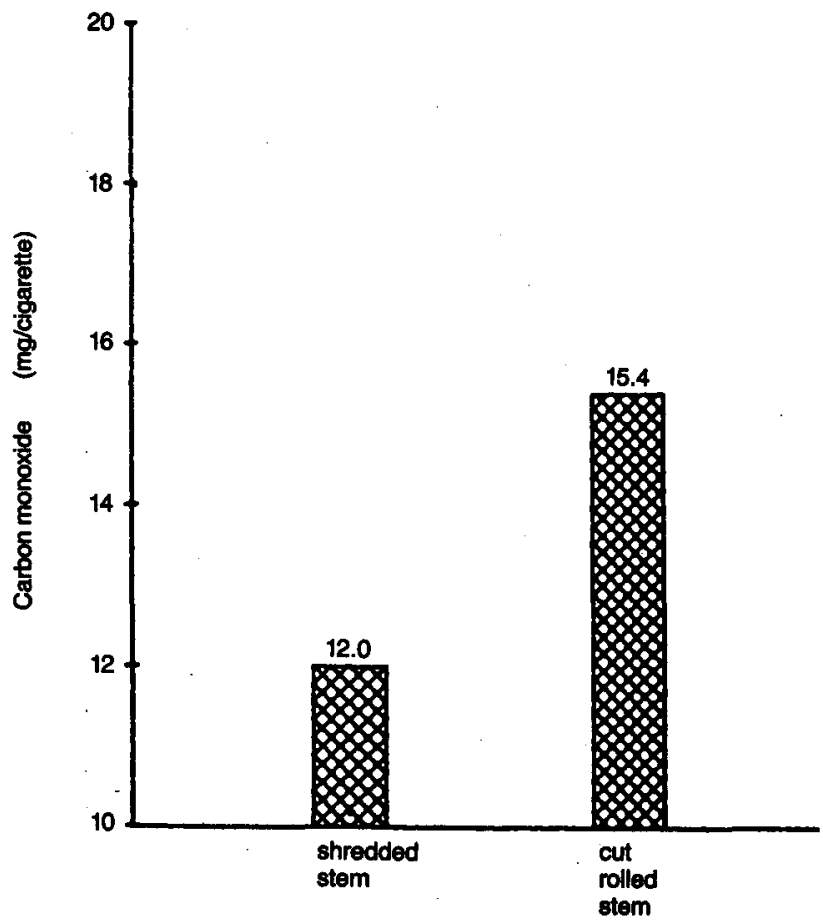


Flgure 11.

Improvement in reduction of CO dellvery.

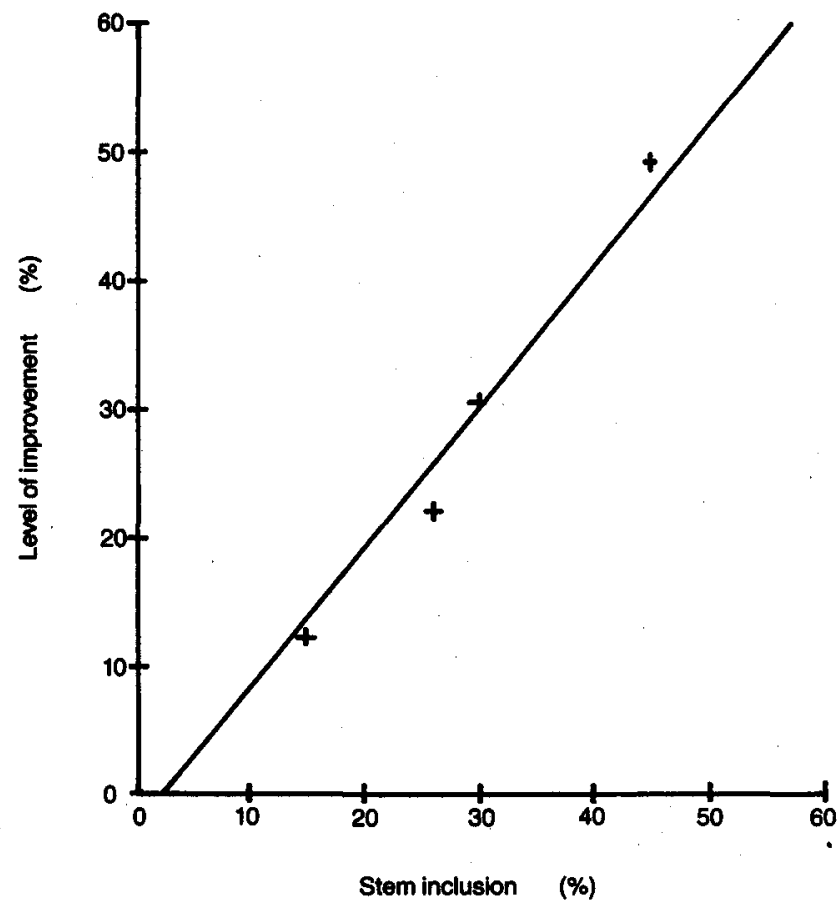

Flgure 13.

Particle slze analysis of stem: $12 \%$ improvement.

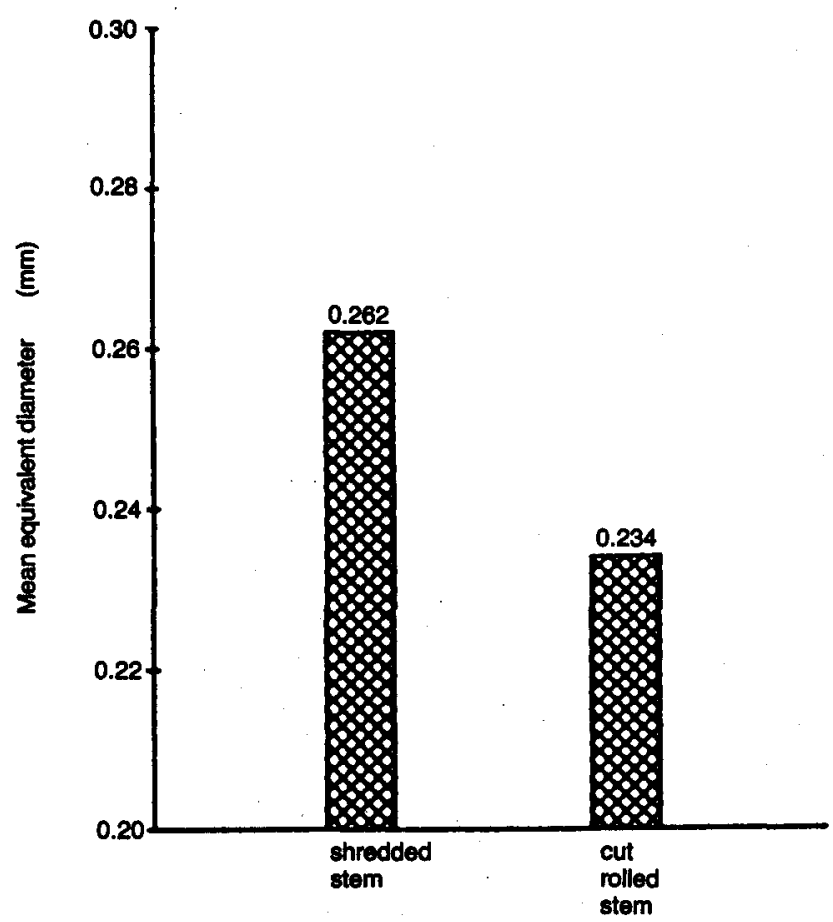

Figure 12.

End stability: $30 \%$ improvement.

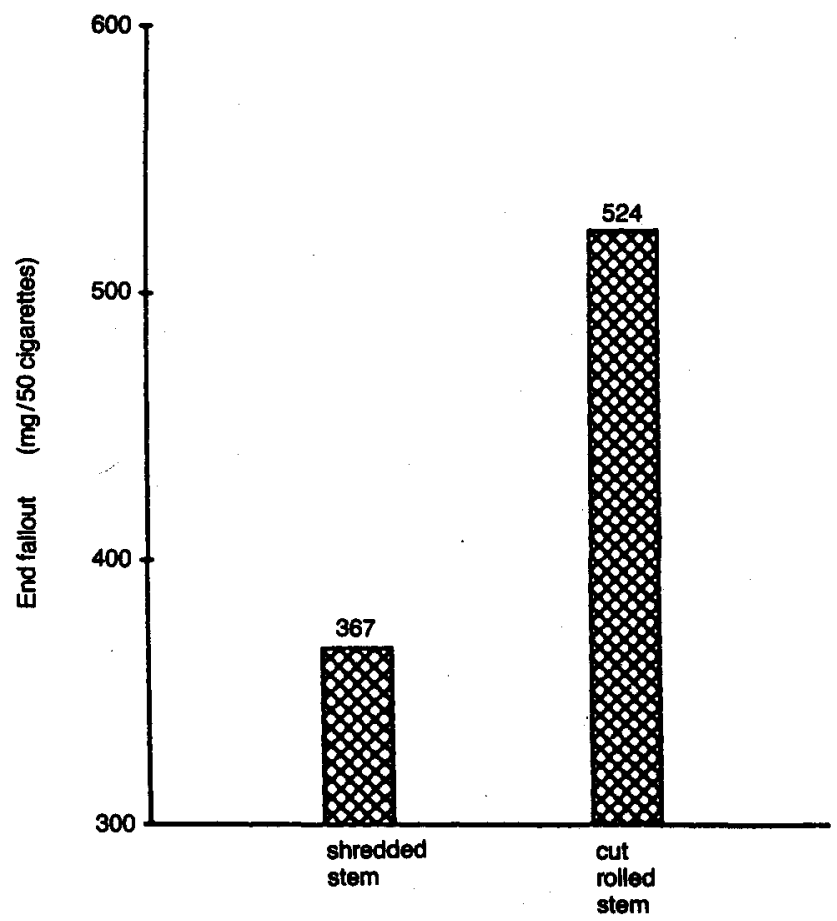

Figure 14.

Effect of particle size on end stability (100\% lamina clgarettes).

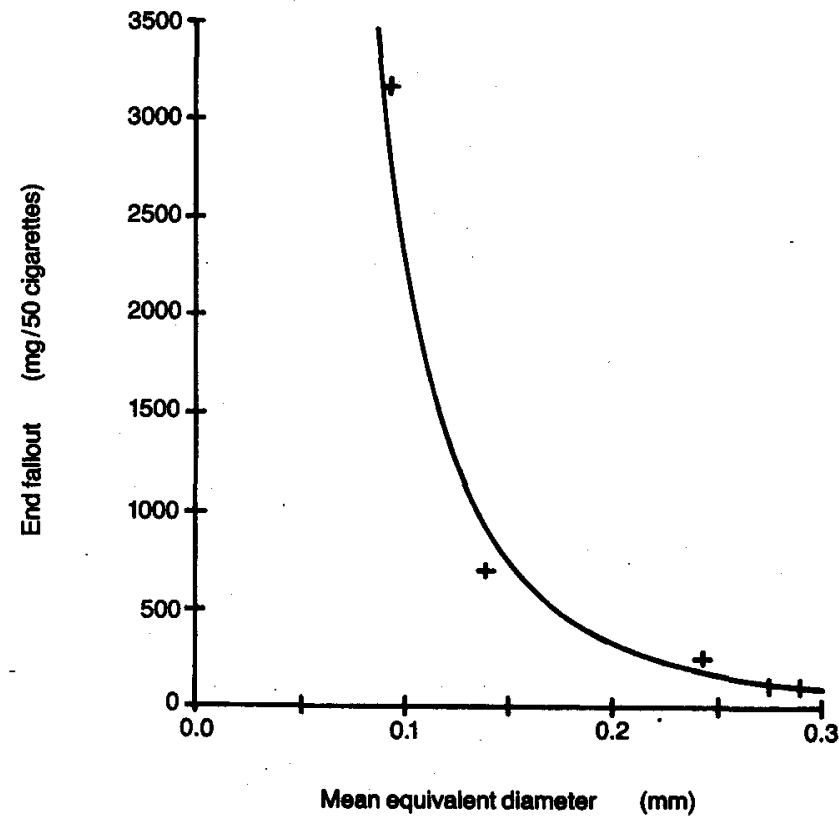


Figure 15.

Concentration of stem in end fallout: $18 \%$ improvement.

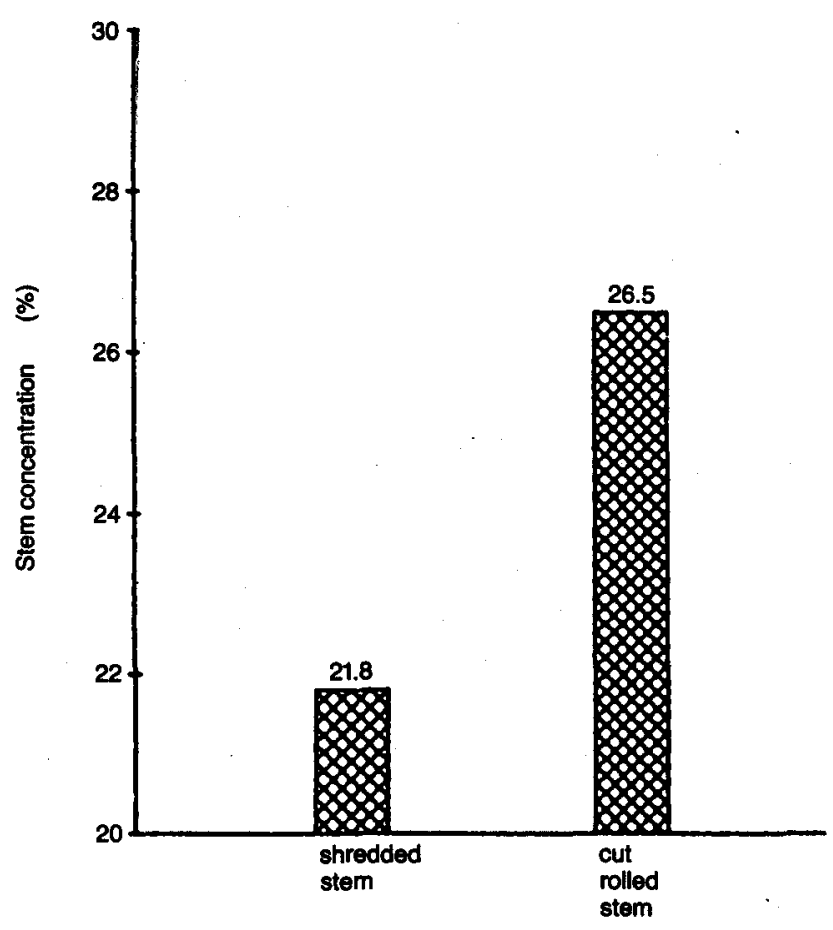

(Bulk filling capacity and all test results are quoted at a sample moisture content of $13.5 \%$.)

The improvement in stem component bulk filling capacity was carried over into the stem-lamina blend. Blend containing shredded stem had a bulk filling capacity improvement of $3.6 \%$ over blend containing cut rolled stem (Figure 4). This value is near the $4.7 \%$ improvement predicted from the mixing of shredded stem into a $26 \%$ to $74 \%$ stem to lamina blend.

Tests conducted on finished cigarettes confirm that the improvement in tobacco firmness results in an improvement in cigarette firmness as well.

Use of the Borgwaldt densimeter in its cigarette testing configuration showed a shredded stem deflection which was $6.7 \%$ lower than the deflection of cigarettes containing cut rolled stem (Figure 5).

The Brinkmann hardness tester (see Appendix 2 for a description of this instrument) confirmed the Borgwaldt results with a firmness improvement of $8.3 \%$ for cigarettes containing shredded stem (Figure 6).

Calculation of the cigarette filling index (see Appendix 3) from the Borgwaldt compression results yielded a $4.5 \%$ improvement for cigarettes containing shredded stem over cigarettes containing cut rolled stem (Figure 7). This improvement in filling index is equivalent to a tobacco weight saving of $41 \mathrm{mg}$ per cigarette.

\section{PRODUCT DEVELOPMENT' POTENTIAL}

The use of shredded stem in cigarettes modifies a variety of burn characteristics. These modifications are ad-
Figure 16.

Duration of burn with puffing (one 2-8econd, $35 \mathrm{~cm}^{3}$ puff per minute): $\mathbf{1 0 \%}$ Increase.

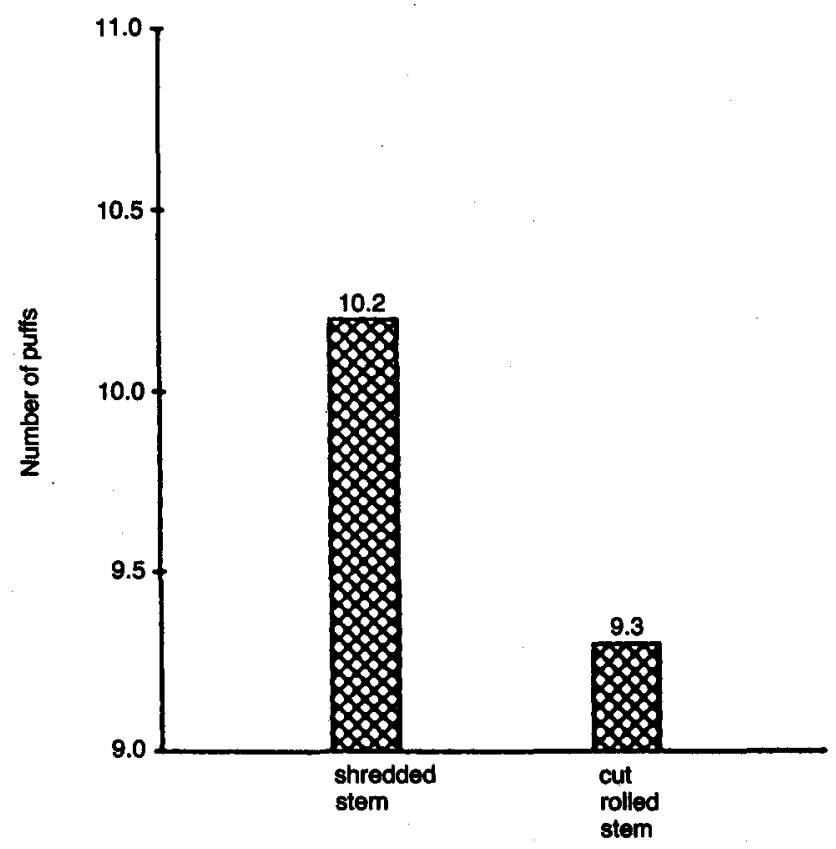

vantageous from the point of view of potential for product development.

Shredded stem cigarettes have a $13 \%$ lower pressure drop than cut rolled stem cigarettes (Figure 8). This allows the manufacturer to use a more efficient filter without producing too great a pressure drop in the cigarette.

The nicotine delivery of shredded stem cigarettes is enhanced by $13 \%$ (Figure 9). This is in spite of the fact that there is no significant change in the "tar" delivery of the cigarettes. This combination of factors is especially advantageous in that it allows the production of low tar cigarettes which still have the capability of a higher nicotine delivery than would be possible with a cut rolled stem cigarette.

A very important burn modification is the $22 \%$ reduction in carbon monoxide delivery of shredded stem cigarettes (Figure 10). Figure 11 demonstrates that the level of reduction of CO delivery is proportional to the level of shredded stem inclusion in the tobacco blend.

The combination of these three burn modifications $\mathrm{fa}$ cilitates the design of either low tar and low $\mathrm{CO}$ cigarettes with enhanced nicotine delivery and acceptable pressure drop or full flavoured, low $\mathrm{CO}$ cigarettes with high nicotine impact and ease of draw.

\section{OTHER PRODUCT IMPROVEMENTS}

An important improvement in the characteristics of cigarettes containing shredded stem is a $30 \%$ reduction in end fallout (Figure 12). This improvement results 
Flgure 17.

Duration of burn without puffing in seconds per $40 \mathrm{~mm}$ of smoulder: $12 \%$ increase.

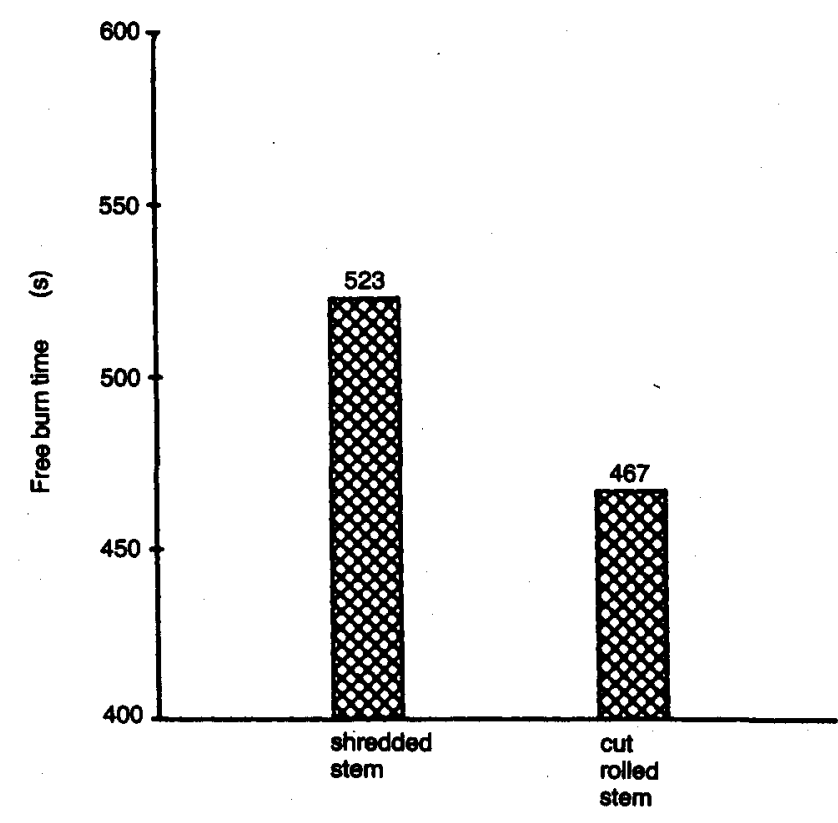

Table 1.

Summary of comparisons.

\begin{tabular}{|c|c|c|c|}
\hline Property & $\begin{array}{l}\text { Shredded } \\
\text { stem }\end{array}$ & $\begin{array}{l}\text { Cut } \\
\text { rolled } \\
\text { stem } \\
\text { (CRS) }\end{array}$ & $\begin{array}{c}\text { Improvement } \\
\text { (based on } \\
\text { CRS standard) } \\
(\%)\end{array}$ \\
\hline $\begin{array}{l}\text { Bulk filling capacity of } \\
\text { stem }\left(\mathrm{cm}^{3} / \mathrm{g}\right)^{*}\end{array}$ & 5.72 & 4.85 & 18 \\
\hline $\begin{array}{l}\text { Bulk filling capacity of } \\
\text { biend }\left(\mathrm{cm}^{3} / \mathrm{g}\right)^{*}\end{array}$ & 4.92 & 4.75 & 3.6 \\
\hline $\begin{array}{l}\text { Borgwaldt deflection } \\
(\mathrm{mm})^{*}\end{array}$ & 2.10 & 2.25 & 6.7 \\
\hline Brinkmann hardness* & 144 & 133 & 8.3 \\
\hline Filling index (mg) ${ }^{*}$ & 878 & 919 & 4.5 \\
\hline $\begin{array}{l}\text { Pressure drop } \\
\left(\mathrm{mm} \mathrm{H} \mathrm{H}_{2} \mathrm{O}\right)\end{array}$ & 83 & 95 & 13 \\
\hline $\begin{array}{l}\text { Nicotine dellvery } \\
\text { (mg/cig.) }\end{array}$ & 1.43 & 1.27 & 13 \\
\hline CO dellvery (mg/clg.) & 12.0 & 15.4 & 22 \\
\hline $\begin{array}{l}\text { End fallout } \\
\text { (mg/50 cig.) }\end{array}$ & 367 & 524 & 30 \\
\hline $\begin{array}{l}\text { Mean equivalent } \\
\text { dlameter }(\mathrm{mm})\end{array}$ & 0.262 & 0.234 & 12 \\
\hline $\begin{array}{l}\text { Stem in end fallout } \\
(\%)\end{array}$ & 21.8 & 26.5 & 18 \\
\hline
\end{tabular}

- Corrected for a molsture content of $13.5 \%$ (all other properties are quoted at equilibrium molsture content).

Table 2.

Other sample characteristice.

\begin{tabular}{l|r|r}
\hline \multicolumn{1}{c|}{ Property } & $\begin{array}{c}\text { Shredded } \\
\text { stem }\end{array}$ & $\begin{array}{c}\text { Cut } \\
\text { rolled } \\
\text { stem }\end{array}$ \\
\hline Equillbrium moisture content (\%) & 14.2 & 14.1 \\
Cigarette weight (mg) & 1065 & 1065 \\
"Tar" delivery (mg/cig.) & 15.2 & 16.2 \\
Pressure drop (mm $\mathrm{H}_{2} \mathrm{O}$ ) & 83 & 95 \\
Burn duration with puffing (puffs) & 10.2 & 9.3 \\
Burn duration without puffing (s) & 523 & 467 \\
Chemical composition (\%) ${ }^{\star *}:$ & & \\
$\quad$ nicotine & 2.0 & 2.0 \\
chloride & 1.3 & 1.3 \\
sugar & 19.6 & 18.9 \\
ash & 15.0 & 14.7 \\
\hline
\end{tabular}

" Corrected for a moisture content of $13.5 \%$.

" Determined at 0\% moisture content.

All other properties are quoted at equilibrium moisture content. 
from the long, fibrous structure of the shredded stem. The mean equivalent diameter of shredded stem and cut rolled stem are compared in Figure 13 (see Appendix 4 for method of determining mean equivalent diameter). The effect of the $12 \%$ increase in particle length is a greater ability of shredded stem particles to anchor themselves and their neighbours within a cigarette's tobacco column.

Figure 14 demonstrates the relationship between mean equivalent diameter and end fallout in cigarettes manufactured from $100 \%$ lamina ( $100 \%$ lamina was used to ensure a homogeneous particle size distribution).

The concentrations of stem in the end fallout of cigarettes (determined by means of the application of $\mathrm{LiCl}$ as a stem component tracer) containing a blend of $26 \%$ stem and $74 \%$ lamina are shown in Figure 15 . The $18 \%$ reduction in stem concentration for shredded stem cigarettes is a measure of the improved anchoring of the longer shredded stem particles within the tobacco column.

\section{DISCUSSION}

The above tests clearly indicate that the characteristics of shredded stem are superior to those of cut rolled stem.

This superiority results in manufacturing cost savings, greater product development potential and greater cigarette end stability.

A summary of these improvements is given in Table 1. Other sample characteristics are listed in Table 2.

Appendix 1.

Detalled process comparison.

\begin{tabular}{l|l|l}
\cline { 2 - 3 } & \multicolumn{1}{|c|}{ Shredding process } & $\begin{array}{c}\text { Cut rolled stem (CRS) } \\
\text { process }\end{array}$ \\
\hline $\begin{array}{l}\text { Tobacco } \\
\text { origin }\end{array}$ & $\begin{array}{l}\text { Whole flue-cured Virginia leaf (stem and lamina) } \\
\text { grown in the southern Ontarlo (Canada) } \\
\text { tobacco region. }\end{array}$ \\
\cline { 2 - 3 } &
\end{tabular}

Threshing In-line green leaf threshing using rotary

process hammer mill and basket.

Output moisture for stem and lamina: $12.5 \%$.

Stem length at output: approximately $5 \mathrm{~cm}$.

Lamina $\quad$ Lamina opened and preconditioned (to $16 \%$ ) by

process Rothmans Tobacco Opening Process.

Conditioning (Cardwell rotary cylinder): $22 \%$.

Bulking: 4 hours.

Cutting (Legg RC3 cutters): at $21 \%$ and $0.75 \mathrm{~mm}$ cut width.

\begin{tabular}{|c|c|c|}
\hline $\begin{array}{l}\text { Stem } \\
\text { processes }\end{array}$ & $\begin{array}{l}\text { Conditioning (rotary } \\
\text { cylinder): } 50 \%-55 \% \text {. } \\
\text { Bulking: } 90 \text { minutes. } \\
\text { Steaming: } 500 \text { mm Hg } \\
\text { gauge steam pressure. } \\
\text { Shredding: } 50 \%-55 \% \\
\text { moisture, } 3.5 \text { mm blade } \\
\text { gap, } 1160 \text { r.p.m. blade } \\
\text { speed (each blade). } \\
\text { Predrier (hot air pneu- } \\
\text { matic tube): } 40 \%-45 \% \\
\text { output moisture. } \\
\text { Drier (rotary cylinder): } \\
\text { 19\%-21\%. } \\
\text { Fine particle removal } \\
\text { (vibrating screen con- } \\
\text { veyor): U.S. No. } 14 \\
\text { screen, } 32 \% \text { removal. }\end{array}$ & $\begin{array}{l}\text { Conditioning (Legg ro- } \\
\text { tary cylinder): } 30 \% \text {. } \\
\text { Bulking: } 3 \text { hours. } \\
\text { Flattening (Legg flat- } \\
\text { teners): } 0.5 \mathrm{~mm} \text { gap. } \\
\text { Cutting (Legg SS } \\
\text { cutters): } 0.2 \mathrm{~mm} \text { cut } \\
\text { width. } \\
\text { Rewetting (expansion } \\
\text { augers): } 43 \% \\
\text { Drying (ITM rotary } \\
\text { cylinder): } 21 \% \text {. } \\
\text { Bulking: } 3 \text { hours. }\end{array}$ \\
\hline
\end{tabular}

\begin{tabular}{|c|c|c|}
\hline & Shredding process & $\begin{array}{l}\text { Cut rolled stem (CRS) } \\
\text { process }\end{array}$ \\
\hline Throughput & $\begin{array}{l}1400 \mathrm{~kg} / \mathrm{h} \text { at } 21 \% \\
\text { moisture (controlled by } \\
\text { weighbelt at shredder). }\end{array}$ & $\begin{array}{l}1700 \mathrm{~kg} / \mathrm{h} \text { at } 21 \% \\
\text { moisture. }\end{array}$ \\
\hline $\begin{array}{l}\text { Costs } \\
\text { (Cdn.\$) } \\
\text { based on } \\
1600 \mathrm{~kg} / \mathrm{h} \\
\text { throughput }\end{array}$ & $\begin{array}{l}\text { Refiners ( } 2 \text { at } 1800 \mathrm{~kg} / \mathrm{h} \\
\text { each }-1 \text { running, } \\
1 \text { standby): } \\
2 \times \$ 220,000=\$ 440,000 \text {. } \\
\text { Bulking silo: } \$ 40,000 \text {. } \\
\text { Predrier: } \$ 35,000 \text {. } \\
\text { Ancillary (motors etc.): } \\
\$ 10,000 \text {. } \\
\text { Total: } \$ 525,000 \text {. }\end{array}$ & $\begin{array}{l}\text { Flatteners ( } 4 \text { at } 600 \mathrm{~kg} / \mathrm{h} \\
\text { each }-3 \text { running, } \\
1 \text { standby): } \\
4 \times \$ 40,000-\$ 160,000 \text {. } \\
\text { Cutters ( } 3 \text { at } 800 \mathrm{~kg} / \mathrm{h} \\
\text { each }-2 \text { running, } \\
1 \text { standby): } \\
3 \times \$ 250,000=\$ 750,000 \text {. } \\
\text { Expansion augers }(2): \\
2 \times \$ 50,000-\$ 100,000 \text {. } \\
\text { Total: } \$ 1,010,000 \text {. }\end{array}$ \\
\hline
\end{tabular}

All other processing equipment is common for the two processes.

All other costs (energy, manpower, space requirements etc.) are comparable for the two processes.

Stem-lamina blending.

Thayer weighbelt for lamina metering tube.

Dickinson weighbelt with custom electronics for stem metering tube.

Stem weighbelt controlled as a slave of the lamina weighbelt to give a $26 \%: 74 \%$ stem to lamina ratio. Both components blended at $21 \%$ moisture.

Total blend weight: $7175 \mathrm{~kg}$ (at $21 \%$ moisture).

Blend dried to $15 \%$ in Legg rotary cylinder drier (with counter flow air) for cigarette manufacture. 
Another change in product characteristics is an increase in duration of cigarette burn. Shredded stem cigarettes have a $10 \%$ increase in burn duration with puffing (one 2-second, $35 \mathrm{~cm}^{3}$ puff per minute (Figure 16)) and a $12 \%$ increase in burn duration without puffing (time to smoulder $40 \mathrm{~mm}$ in calm air (Figure 17)).

The use of shredded stem has no significant effect on the chemical composition of the tobacco (nicotine, chloride, sugar or ash abundances), on the flavour char- acteristics of the cigarette (as determined by flavour panel) or on the ${ }^{*} \operatorname{tar}^{\star}$ delivery of the cigarette.

Author's address:

Product Research and Development Laboratory, Rothmans of Pall Mall Limited, 75 Dufflaw Road, Toronto, Ontario, M6A 2W4, Canada.

Appendix 2.

Brinkmann hardness test.

The Brinkmann hardness tester (developed by Martin Brinkmann $A G$ of West Germany) measures the firmness of the cigarette by lowering a series of small weights (1.5 grams each) onto the cigarette over the entire length of the tobacco column.

Individual llght sources and detectors (acting as microswitches) measure the length of time required for the weights to depress the tobacco column by a standard amount.

The hardness equation calculates a firmness modulus from average length of time, initial diameter and moisture content.

Appendix 3.

FIlling Index measurement.

The filling index value is a measure of the amount of tobacco required to fill a standard length clgarette to a standard level of firmness.

Filling Index is calculated from tobacco column weight, molsture content and Borgwaldt deflection.

\section{Appendix 4.}

Determination of mean equlvalent diameter.

The calculation of the mean equivalent diameter is based on the classification of particles by sleving through a sequence of standard U.S. screen sizes (1/4 inch, No. 8, No. 14, No. 30, No. 50 and Pan). It is assumed that particles coming to rest on any screen have a size halfway between that of the opening of the screen above (through which the particle passed) and that of the opening of the screen on which the particle rested (through which the particle did not pass).

The mean equivalent diameter is the weighted average of the sizes of all the particles in the sample.

Mean equivalent diameter $=\sum_{i=1}^{n}\left(W_{i}\left(S_{i}+S_{i-1}\right) / 2\right) / \sum_{i=1}^{n} W_{i} \quad$,

where $S_{1}$ is the size of the opening in screen $i$ (screen 0 is a hypothetical $1 / 2$ inch screen on which no particle would rest) and $W_{t}$ is the weight of particles resting on screen $\mathrm{i}$. 